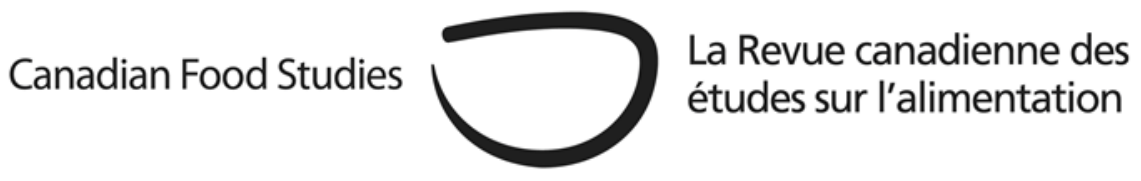

Book Review

\title{
Frontline farmers: How the National Farmers Union resists agribusiness and creates our new food future
}

\author{
Edited by Annette Aurélie Desmarais \\ Fernwood Publishing, 2019: 276 pages
}

Review by Rebecca Ellis*

The new book Frontline Farmers: How the National Farmers Union Resists Agribusiness and Creates Our New Food Future edited by Annette Aurélie Desmarais is an important first-hand account of the activism of the National Farmers Union (NFU) over the past five decades. Written for a general audience, this book is organized by chapters based on various struggles in which the NFU has been involved. Each chapter begins with an introduction that includes contextual information necessary to understand the issues. The majority of each chapter is devoted to a transcribed conversation between NFU members involved in that struggle. This conversational approach allows nuances to emerge and complexity to be explored. It also allows small-scale farmers to share their considerable expertise based on their intimate, lived experiences on the land. This exploration of the diverse struggles and campaigns waged by NFU members against the corporatization of the food system provides an important account of the agrarian movement in Canada. The NFU's steadfast commitment to ecological and social justice, and to working in solidarity with other social movements, is a common thread throughout Frontline Farmers.

The NFU represents thousands of small-scale farmers across Canada. The campaigns that the NFU has waged against the corporatization of the food system are noteworthy due to both the scale of organizing and their impact. Although a much smaller organization than commoditybased farmer organizations, the NFU has engaged in highly effective campaigns that utilise a diversity of activist tactics and strategies including direct action, rolling blockades, mass leafletting, and the building of alliances that cross divides, most notably the urban/rural divide. For example, during the Boycott of Kraft Foods in the 1970s, NFU activists employed mass picketing in cities across the country as well as urban-based protests and actions. The chapter on the closing of the prison farms in Kingston, ON in 2010 is especially illustrative in detailing the 
trajectory of a highly transformative campaign. Meaningful alliances were made between farmers and prisoner rights activists and tactics were undertaken, in some cases by first-time activists, that included blockading prison entrances and risking arrest. The Save the Prison Farm movement was successful in reversing some of the closures but perhaps more importantly, forced a national conversation to occur about prison farms and prisoners' rights.

While reading this book, I was struck by the NFU's deep commitment to solidarity beyond campaign-based alliance building. This is especially clear in the chapter on the NFU's international work with La Via Campesina, the international peasants' organization of which they were a founding member. In the chapter on building Indigenous-settler solidarity, NFU activists grapple with the contradictions and tensions of farming in a colonial-settler state. This conversation is especially important given the murder of Colten Boushie, a young Indigenous man who was shot in the back of the head by a Saskatchewan farmer, Gerald Stanley, in 2016. Stanley was acquitted of murder, an indication of the deep-rooted racism towards Indigenous people in rural Saskatchewan. The commitment by NFU activists to act in solidarity with Indigenous people against continued acts of colonialization is essential for the creation of a just food system.

This book does not shy away from detailing the struggles that occurred within the organization, something illuminated in the chapter on agrarian feminism. Although a progressive organization from its inception in 1969, the women in this chapter discuss encountering sexist attitudes and behaviours within the NFU, including being confronted by men about the legitimacy of their leadership. This chapter is very effective at bringing young women into conversation with women who were struggling for a place and voice in the NFU in the 1970s and 1980s, providing a rich and dynamic history of the NFU and of the feminist movement.

Throughout the book, several farmers discuss the negative impact on NFU members and campaigns when universities in Canada began to cut research and extension work with smallscale farmers. There is a general feeling expressed throughout the book that academic research has become increasingly corporatized. This neo-liberalization of the academy has directly impacted farmers who, in struggles over pesticides such as neonicotinoids and genetically engineered seeds, are often confronted with scientific studies directly commissioned and strategically deployed on behalf of agribusinesses. There is clearly a need for more research to be conducted with and about small-scale farmers in Canada.

Although there are chapters of the book that seriously grapple with the concept of solidarity, very little was mentioned (or asked) about migrant farm workers who make up a significant portion of the workforce on farms, particularly crop production in Ontario ${ }^{1}$. Although NFU farmers may employ significantly fewer migrant farmworkers than large-scale agribusiness operations, it seems like a missed opportunity to discuss workers' rights, migrants' rights, and racism within the food system and within rural communities. One minor critique of the book is

\footnotetext{
${ }^{1}$ Agricultural sector workers from the Temporary Foreign Workers Program, 2015
} 
that it would have been useful to conclude with a chapter that explores some of the future challenges and possibilities for small-scale farmers in Canada. I am interested to know what NFU activists think about the growth in urban agriculture, the challenges presented by climate change, and strategies for countering high-tech venture capitalist-backed approaches to farming.

Frontline Farmers is an important read for activists, students, and scholars. It provides an especially rich history of the agricultural system in Canada in the late $20^{\text {th }}$ century and early $21^{\text {st }}$ century from the perspective of grassroots activists and small-scale farmers. It would be an excellent addition to any food systems course. The activism and advocacy conducted by NFU members over the past five decades has given me a new perspective on farming and rural life in Canada, one that is hopeful about the possibilities of the creation of an agricultural system that is ecologically regenerative and socially just. Highly recommended.

Rebecca Ellis is currently completing her PhD in Geography at Western University. Her PhD dissertation is about the relationship between urban bees and people in cities, with a focus on the practices of urban beekeeping and pollinator gardening. She is also working on a book about capitalist agriculture and pollinator health. In addition to academic work, Rebecca is a permaculture practitioner, community activist, and beekeeper. 